\title{
Effect of Notch Severity on Fatigue Behaviour of ADI Castings
}

\author{
Khaled M. Ibrahim ${ }^{1}$, Bakkar El-Sarnagawy ${ }^{2}$, Ibrahim I. Saleh ${ }^{2}$ \\ ${ }^{1}$ Central Metallurgical Research and Development Institute, Cairo, Egypt; ${ }^{2}$ Modern Academy for Engineering \& Technology, Cairo, \\ Egypt. \\ Email: khaledabouelela@yahoo.com
}

Received November $27^{\text {th }}, 2012$; revised December $24^{\text {th }}, 2012$; accepted January $21^{\text {st }}, 2013$

\begin{abstract}
An investigation was carried out to examine the influence of notch sensitivity on fatigue behaviour of austempered ductile iron (ADI). Samples were made of ductile iron with a chemical composition of 3.55\% C, $2.18 \% \mathrm{Si}, 0.35 \% \mathrm{Mn}$, $0.022 \% \mathrm{P}, 0.008 \% \mathrm{~S}$ and $0.045 \% \mathrm{Mg}$. The samples were heat treated by austenitizing at $900^{\circ} \mathrm{C}$ for $1 \mathrm{~h}$ and then rapidly quenched into two different salt baths at $350^{\circ} \mathrm{C}$ and $400^{\circ} \mathrm{C}$ for $1 \mathrm{~h}$ each. This work aims at studying the capability of mechanical stress analysis software (ANSYS 12.0), as a nondestructive tool, to characterize and quantify the fatigue strength of the notched ADI samples with different radii (from 1 to $3 \mathrm{~mm}$ ). In addition, experimental testing was performed using rotary bending fatigue machine on notched samples with radii of 1, 1.5 and 2-mm to verify the theoretical data obtained by ANSYS-12. The results show that the predicted fatigue strength estimated by ANSYS-12 is very close to the experimental one. Therefore, fatigue performance of the rotating parts made of ADI can be estimated theoretically using ANSYS 12.0. The fatigue strength of these parts can also be improved by increasing the formed filled radius due to decreasing the notch sensitivity factor.
\end{abstract}

Keywords: ADI; ANSYS-12; Fatigue; Notch Sensitivity

\section{Introduction}

Austempered ductile iron (ADI) is widely used in Industry because it offers a combination of low cost, design flexibility, high strength-to-weight ratio, good toughness, wear resistance, and fatigue strength [1-3]. Generally, ADI alloys possess mechanical properties that are superior to conventional ductile iron and comparable to heat treated forged steels $[4,5]$. These attractive properties of ADI are related to its unique microstructure that consists of ferrite and high carbon austenite which is often referred to as ausferrite [6]. One of the main advantages of ADI is the variability of mechanical properties which can be influenced in a very wide range by changing the isothermal conditions i.e. austempering temperature and time $[7,8]$. Some researches on high cycle fatigue behaviour of ADI indicated that fatigue limit is increased with increasing the amount of retained austenite in matrix due to the high strain-hardening nature of the austenite phase [9-11]. Stokes et al. [12] also reported that existing large amount of low carbon retained austenite in matrix would undergo martensitic transformation under plastic deformation for the ADI austempered at higher temperature $\left(>350^{\circ} \mathrm{C}\right)$. The high strength and toughness of ADI compared with forged steel made it attractive for wide range of applications. ADI is also used for rotating crankshafts where fillets and notches are part of the design. Normally, notches produce highly stress concentration in the shaft which consequently reduces the rotating bending fatigue strength. Notch sensitivity tests for ADI are very rare and experiments made are seldom, so only few data are available. Most of the fatigue data available on ADI covers smooth-walled samples and the availability of good design data for notched samples with different radii are limited. Therefore, this research work aims at studying the effect of notch severity on fatigue performance of ductile iron austempered at $350^{\circ} \mathrm{C}$ and $400^{\circ} \mathrm{C}$. Reduction in fatigue limits due to notch effect will be firstly determined analytically using mechanical stress analysis software (ANSYS 12.0) and then verified by conducting experimental tests on a rotary bending fatigue machine.

\section{Experimental Work}

The chemical composition of the cast ductile iron used in this research is; $3.55 \% \mathrm{C}, 2.18 \% \mathrm{Si}, 0.35 \% \mathrm{Mn}, 0.022 \%$ $\mathrm{P}, 0.008 \% \mathrm{~S}$ and $0.045 \% \mathrm{Mg}$. ADI samples were prepared by austenitizing the ductile iron samples isothermally for one hour at $900^{\circ} \mathrm{C}$. The austempering process was performed in a salt bath at two different austempering temperatures of $350^{\circ} \mathrm{C}$ and $400^{\circ} \mathrm{C}$ for one hour each. Then the samples were cooled using forced air. Micro- 
structural investigation was carried out according to the standard procedures. The amount of retained austenite was estimated using X-ray diffraction. Tensile, hardness, impact tests were performed to verify the mechanical properties for the samples austempered at $350^{\circ} \mathrm{C}$ and $400^{\circ} \mathrm{C}$.

Rotating bending fatigue technique was used to evaluate the fatigue behaviour of un-notched and notched ADI samples. Un-notched fatigue samples were machined as round bars of 8-mm diameter and 130-mm long, as can be seen in Figure 1(a). While, the notched samples were machined with various notch radii ( $\mathrm{R} 1,1.5,2 \mathrm{~mm})$, as shown in Figure 1(b). For the notched samples, the core diameter was kept constant at $4 \mathrm{~mm}$ for all formed notch radii, as shown in Figure 2. Before testing, the specimens were ground to eliminate any surface defects. All fatigue tests were performed using high cycle fatigue regime. The test was run to failure or to $10^{7}$ cycles at which samples were considered to be a run-out. S-N curves were established for each group of samples with the same notch radius. Ten to twelve samples of each condition and geometry were tested with sufficient stress levels to obtain reliable S-N curves and fatigue limits. An analytical study was made using mechanical stress analysis software (ANSYS 12.0) for predicting stress concentration and fatigue strength vs. life time of the studied ADI.

\section{Results and Discussions}

\subsection{Microstructure Investigation}

Figures 3(a) and (b) shows the microstructure of the investigated ADI samples austempered at $350^{\circ} \mathrm{C}$ and $400^{\circ} \mathrm{C}$, respectively. The austempering temperature of $350^{\circ} \mathrm{C}$ resulted in forming a mixed ausferritic structure which consisted of fine and coarse bainitic structure, as shown in Figure 3(a). The other samples austempered at $400^{\circ} \mathrm{C}$ showed a feathery large scale bainitic structure, as seen in Figure 3(b). At $350^{\circ} \mathrm{C}$ the structure contains low amount of retained austenite of about $25.8 \%$. However,

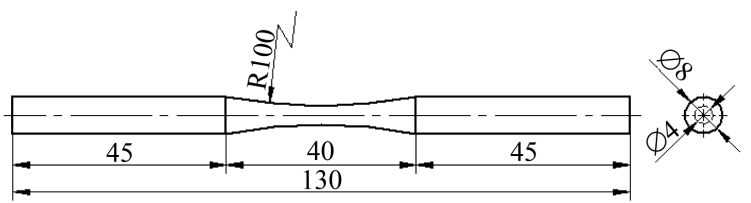

(a)

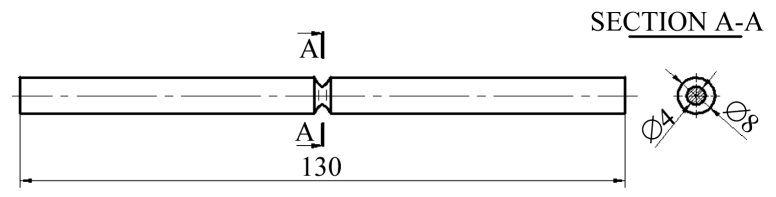

(b)

Figure 1. Un-notched and notched fatigue samples configurations. (a) Un-notched; (b) Notched.

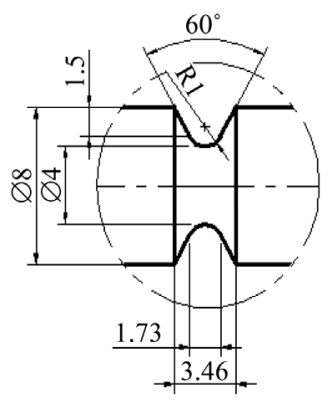

(a)

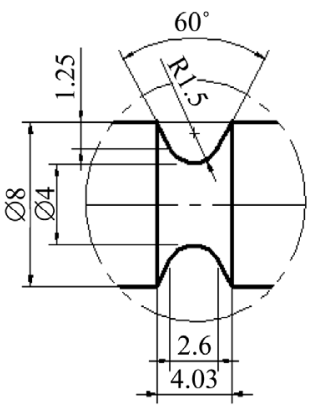

(b)

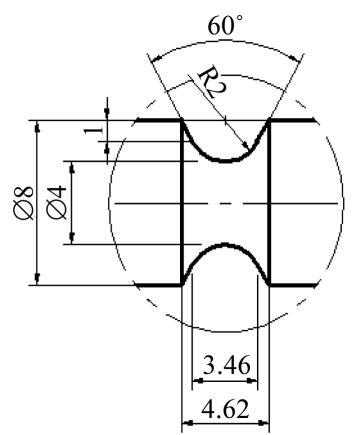

(c)

Figure 2. Schematic drawing of the formed notch radius on the fatigue samples. (a) $1 \mathrm{~mm}$; (b) $1.5 \mathrm{~mm}$; (c) $2 \mathrm{~mm}$.

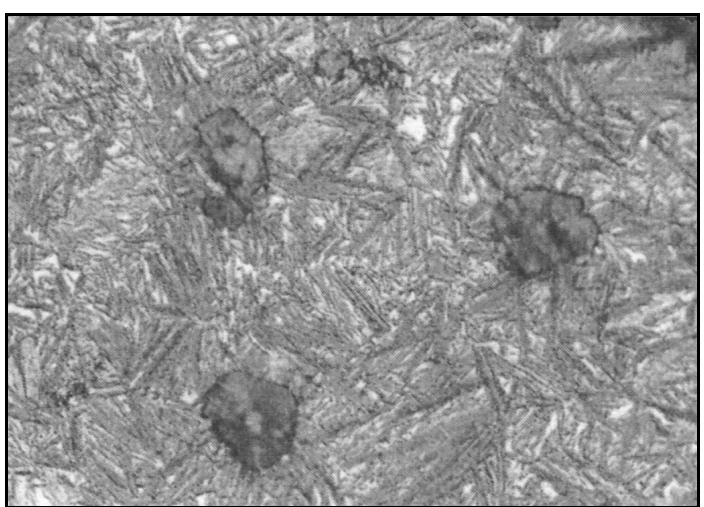

(a)

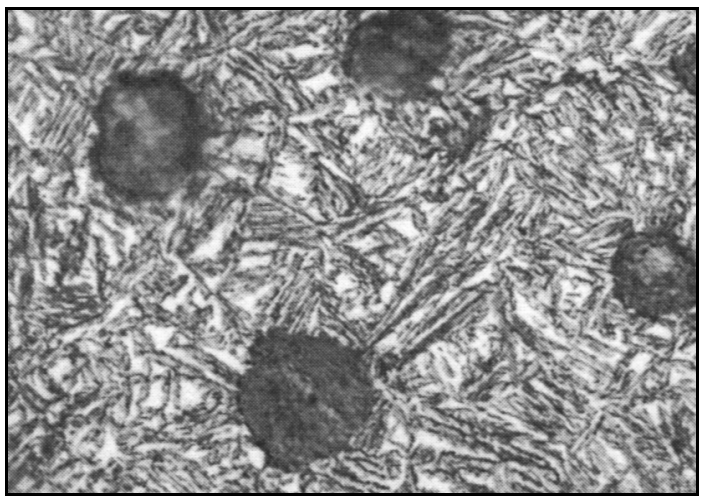

(b)

Figure 3. Microstructure of the investigated DI alloy austempered at: (a) $350^{\circ} \mathrm{C}$; (b) $400^{\circ} \mathrm{C}$. 
the samples austempered at $400^{\circ} \mathrm{C}$ contain higher amount of retained austenite of about $34.7 \%$.

\subsection{Mechanical Properties}

The tensile properties of the studied samples were evaluated and are given in Table 1. The optimum tensile and yield strengths were observed with low austempering temperature of $350^{\circ} \mathrm{C}$ due to the refinement of the ausferritic structure and existing of lower amount of retained austenite in matrix. At $350^{\circ} \mathrm{C}$, the ultimate strength was $1120 \mathrm{MPa}$ and the yield strength was $877 \mathrm{MPa}$. Higher austempering temperature of $400^{\circ} \mathrm{C}$ showed lower tensile and yield strengths $\left(\sigma_{\mathrm{u}}=902 \mathrm{MPa}\right.$ and $\left.\sigma_{\mathrm{y}}=602 \mathrm{MPa}\right)$ compared to the last one. This is due to the nature of the ausferritic structure obtained at $400^{\circ} \mathrm{C}$. In addition, at $400^{\circ} \mathrm{C}$ the samples showed relatively higher ductility (10.4\%) compared to the samples austempered at $350^{\circ} \mathrm{C}$ which gave $7.8 \%$ ductility. The higher ductility observed at $400^{\circ} \mathrm{C}$ is mainly attributed to the presence of higher amount of retained austenite in matrix $[13,14]$. In addition, the austempering temperature of $350^{\circ} \mathrm{C}$ obtained higher hardness value (330 HV) compared to $400^{\circ} \mathrm{C}(297$ $\mathrm{HV}$ ) due to the lower amount of retained austenite existing in matrix and the refinement effect of the ausferritic matrix.

The results of the un-notched impact samples showed also that the austempering temperature of $350^{\circ} \mathrm{C}$ obtained higher impact toughness $(85 \mathrm{~J})$ compared to the other samples austempered at $400^{\circ} \mathrm{C}(62 \mathrm{~J})$. This is attributed to the refinement effect of the ausferritic structure in spite of existing of lower amount of retained austenite in the matrix as compared to ADI samples austempered at $400^{\circ} \mathrm{C}$ [12]. Therefore, refinement of ausferritic structure plays an important role in determining the impact toughness of ADI regardless of the amount of retained austenite existing in matrix.

\subsection{Fatigue Behaviour}

In order to determine the theoretical fatigue strength of the notched fatigue samples with different radii $(1,1.5$, 2 ), some exponents should be firstly known. The properties and exponents of the standard ADI alloy grade 2 (1050-700-07) are matched well with the properties of

Table 1. Mechanical properties of the studied ADI alloy.

\begin{tabular}{lcc}
\hline Mechanical Properties & ADI-350 ${ }^{\circ} \mathrm{C}$ & ADI-400 $^{\circ} \mathrm{C}$ \\
\hline Maximum Tensile Strength (MPa) & 1120 & 902 \\
Yield Strength (MPa) & 877 & 602 \\
Elongation (\%) & 7.8 & 10.4 \\
Hardness (HV 20$)$ & 330 & 297 \\
Impact (J) & 85 & 62 \\
\hline
\end{tabular}

the studied samples austempered at $350^{\circ} \mathrm{C}$. Therefore, it is decided to use the exponents of ADI grade 2 in the mechanical stress analysis software (ANSYS 12.0) for predicting the fatigue strength vs. life time. These properties and exponents are fed into the ANSYS-12 software to predict the fatigue strength and stress concentration for the un-notched and notched samples with the radii of $1,1.5,2,2.5$, and $3 \mathrm{~mm}$. The predicted and experimental fatigue data are listed in Table 2. The samples were modeled in a geometrical module with the same specifications of the machines samples. A finite element mesh was executed for all models using triangular shaped elements, where a resizing factor was considered in the notched radius section, Figure 4. A statical solution was run to obtain the maximum principle stress for the un-notched and notched samples [15-17]. An example showing the existence of maximum principle stress for the samples with notch radius of 2- $\mathrm{mm}$ is presented in Figures 5 and $\mathbf{6}$.

In order to predict the fatigue strength against life time, the fatigue tool was inserted to the software program. A fully reversed cycling bending load was set to the program to simulate the experimental rotary bending fatigue test. Loads were gradually applied until the life time is predicted by complete failure. Therefore, the fatigue

Table 2. Fatigue results for ADI austempered at $350^{\circ} \mathrm{C}$ provided by ANSYS-12.

\begin{tabular}{ccc}
\hline Sample & $\begin{array}{c}\text { Theoretical fatigue } \\
\text { strength at 10 } \\
\text { (ANSYS), (MPa) }\end{array}$ & $\begin{array}{c}\text { Experimental fatigue } \\
\text { strength, (MPa) }\end{array}$ \\
\hline Un-notched & 250 & 250 \\
$\mathrm{R}=1.0 \mathrm{~mm}$ & 219 & 220 \\
$\mathrm{R}=1.5 \mathrm{~mm}$ & 222 & 229 \\
$\mathrm{R}=2.0 \mathrm{~mm}$ & 232 & 235 \\
$\mathrm{R}=2.5 \mathrm{~mm}$ & 241 & N/A \\
$\mathrm{R}=3.0 \mathrm{~mm}$ & 245 & N/A \\
\hline
\end{tabular}

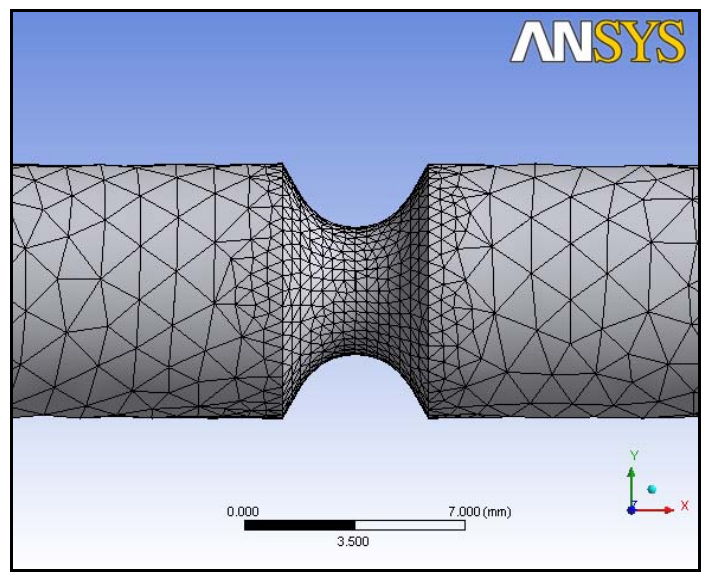

Figure 4. Meshing for $R=2 \mathrm{~mm}$ notched fatigue sample. 


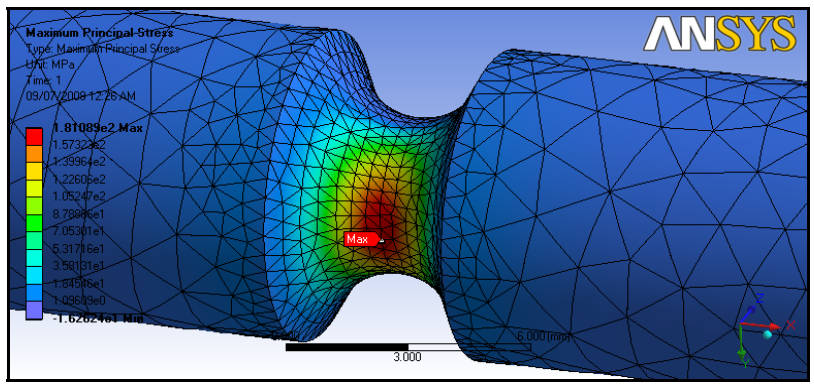

Figure 5. Location of maximum stress for the sample with notch radius of $2 \mathrm{~mm}$.

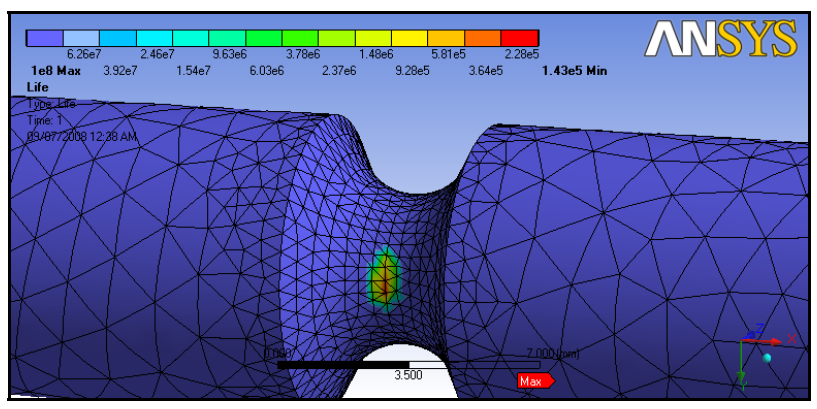

Figure 6. Location of fatigue failure for the sample with notch radius of $2 \mathrm{~mm}$.

strength vs. life time curves can be obtained for each notch radii $(1,1.5,2,2.5$, and $3 \mathrm{~mm})$. Ten runs were applied for each condition with different bending forces. Figures 7(a)-(f) shows the predicted fatigue strength vs. life time for the un-notched and notched conditions with the radii $1,1.5,2,2.5$, and $3 \mathrm{~mm}$. To verify these theoretical data obtained by ANSYS 12.0, experimental tests were carried out for the un-notched and notched samples with notch radii of $1,1.5$ and $2 \mathrm{~mm}$. The S-N for the aforementioned samples is shown in Figure 8.

To compare the predicted data with the experimental ones, the S-N curves are gathered in one curve for the austempered samples at $350^{\circ} \mathrm{C}$, as shown in Figures 9 and 10. It is noticed that there is no significant difference between the theoretical and experimental results. Therefore, the fatigue strength of notched ADI parts can be easily predicted using ANSYS-12.0. The stress concentration factor $\left(\mathrm{K}_{\mathrm{t}}\right)$ is also used to estimate the stress amplification in the vicinity of a geometric discontinuity, where $\mathrm{K}_{\mathrm{t}}=\sigma_{\max } / \sigma_{\min }$. Hence, the fatigue stress concentration factor $\left(\mathrm{K}_{\mathrm{f}}\right)$ can estimate as follows:

$\mathrm{K}_{\mathrm{f}}=\max$ stress in notched specimen/stress in notchfree specimen, or

$\mathrm{K}_{\mathrm{f}}=$ Endurance limit of a notched specimen/Endurance limit of a notch-free specimen.

Then, the notch sensitivity factor (q) can be estimated as;

$$
\mathrm{q}=\left(\mathrm{K}_{\mathrm{f}}-1\right) /\left(\mathrm{K}_{\mathrm{t}}-1\right) \quad \text { where } 0 \leq \mathrm{q} \leq 1
$$

or

$$
\mathrm{K}_{\mathrm{f}}=1+\mathrm{q}\left(\mathrm{K}_{\mathrm{t}}-1\right) \quad \text { where } 1 \leq \mathrm{K}_{\mathrm{f}} \leq \mathrm{K}_{\mathrm{t}} .
$$

Generally speaking, the notch sensitivity factor (q) of a material is a measure of how sensitive a material to notches or geometric discontinuities [1]. Therefore, it was important to estimate the notch sensitivity factors for the studied material. In this study, the stress concentration factor $\left(\mathrm{K}_{\mathrm{t}}\right)$, notch sensitivity factor $(\mathrm{q})$ and fatigue notch factor $\left(\mathrm{K}_{\mathrm{f}}\right)$ were estimated and the data are given in Table 3. The data show certain degree of notch sensitivity, where the theoretical $\mathrm{K}_{\mathrm{t}}$ increases as the notch radius decreases from 3 to $1 \mathrm{~mm}$. It is also noticed that both theoretical and experimental data showed an increase in notch sensitivity factor (q) with decreasing the notch radius. In addition, there is minor difference in values of $\mathrm{K}_{\mathrm{f}}$ for the $\mathrm{ADI}$ samples austempered at $350^{\circ} \mathrm{C}$ $\& 400^{\circ} \mathrm{C}$. The correlation between $\mathrm{q}$ and notch radius for theoretical and experimental results is also plotted, as seen in Figure 11. It is obvious that there is no big difference between the theoretical and experimental results for ADI samples austempered at $350^{\circ} \mathrm{C}$. Accordingly, it could be concluded that fatigue performance of components made of ADI can be enhanced by increasing the notch radius due to decreasing the notch sensitivity factor (q).

It could also be concluded that there is no direct correlation between the austempering temperature and notch severity for the studied ADI samples because the fatigue limit of both investigated austempering temperatures $\left(350^{\circ} \mathrm{C}\right.$ and $\left.400^{\circ} \mathrm{C}\right)$ was mainly dependent on the notch radius and did not depend on the austempering temperature. For the investigated ADI samples austempered at $350^{\circ} \mathrm{C} \& 400^{\circ} \mathrm{C}$, the decrease in fatigue limit will be occurred by decreasing the notch radius from $\mathrm{R}=2$ to 1 $\mathrm{mm}$. The worst case was reported for $1-\mathrm{mm}$ notch radius, where there was a decrease in fatigue limit of about 30 MPa $(\approx 13 \%)$ compared to the un-notched samples. On the other hand, the decrease in fatigue limit was relatively the same for $1-\mathrm{mm}$ and $1.5-\mathrm{mm}$ notch radii, while at 2-mm notch radius the decrease in fatigue strength was the half of the last value, i.e., $6 \%-8 \%$. Therefore in machining of spare parts that made of ADI and subjected to dynamic loading during service, it is recommended to use a notch radius more than 2-mm to keep the fatigue strength as high as possible to avoid failure in service.

The fracture surface of the investigated fatigue samples has been studied. In case of notched samples, the fracture surface showed that cracks were started from the notched surface or just below the surface, Figure 12(a). Cracks were started from the the graphite nodules that located on the surface, as indicated by the arrows in Figure 12(b). However for the notch-free samples, cracks were started inside the cross section of the sample. As 


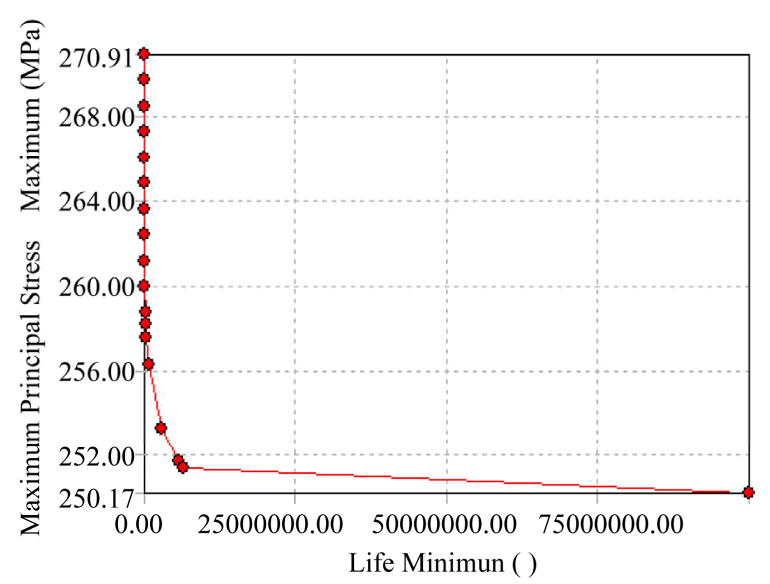

(a)

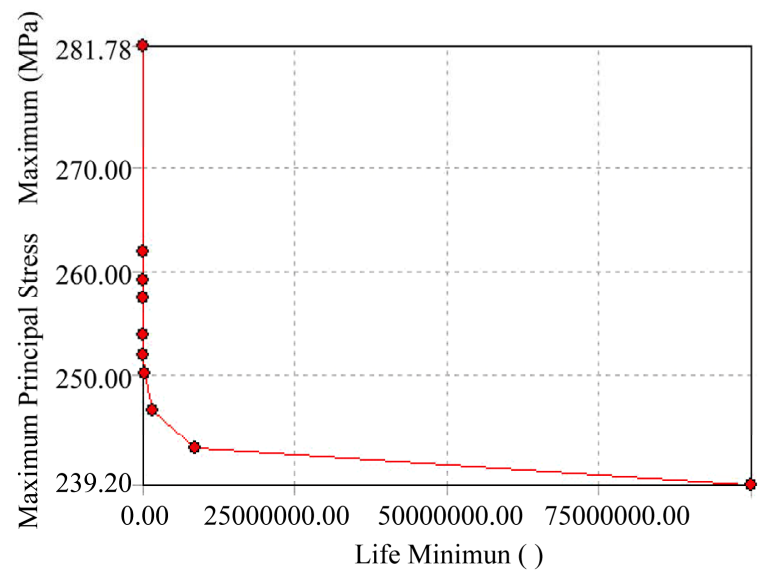

(c)

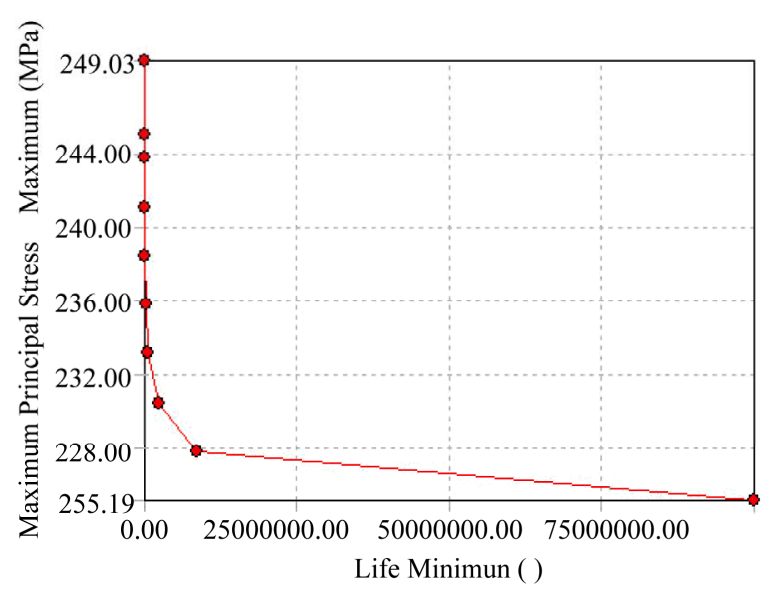

(e)

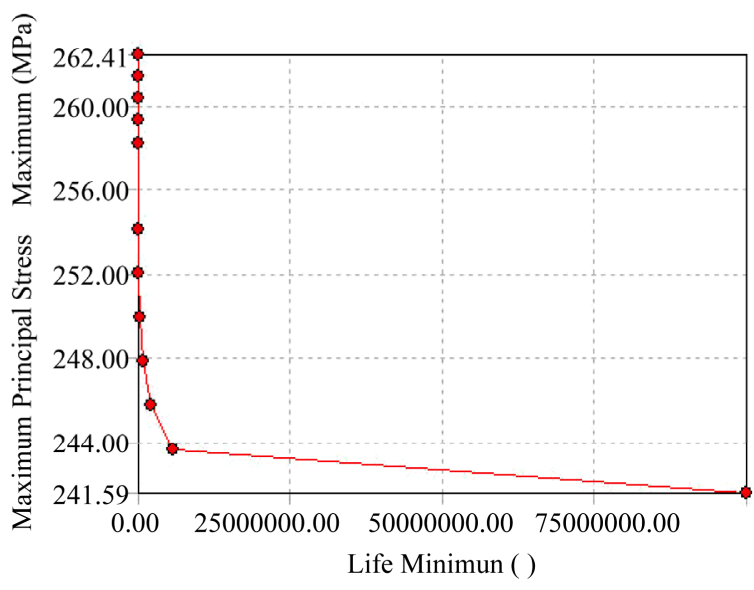

(b)

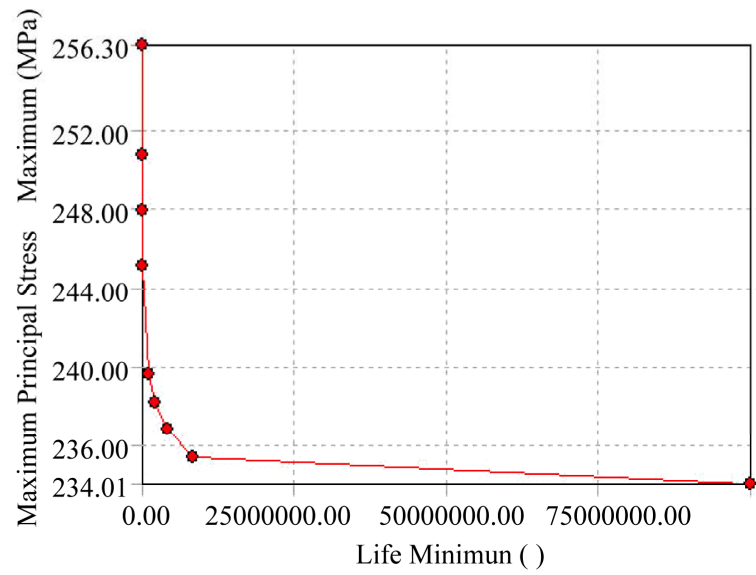

(d)

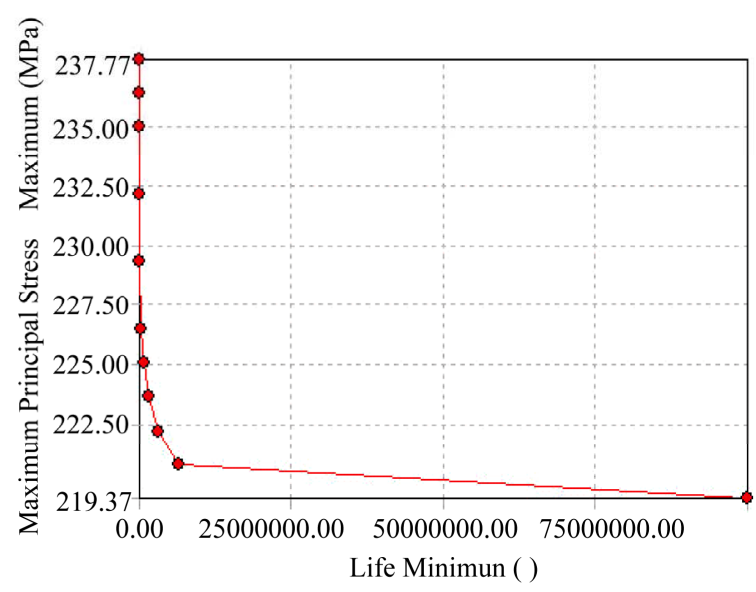

(f)

Figure 7. Predicted fatigue strength vs. life time for un-notched and notched samples of radii $R=1,1.5,2,2.5,3 \mathrm{~mm}$. (a) Un-notched sample; (b) $R=3 \mathrm{~mm}$ notched sample; (c) $R=2.5 \mathrm{~mm}$ notched sample; (d) $R=2 \mathrm{~mm}$ notched sample; (e) $R=1.5$ mm notched sample; (f) $R=1 \mathrm{~mm}$ notched sample.

shown in Figure 13, cracks started also from the graphite nodule and went through the matrix till the next graphite nodule acting as crack arrest. There was also a difference in crack width of the un-notched and notched fracture surfaces, where the notched samples showed a wider crack width of about $4 \mu \mathrm{m}$, Figure 14(a). However, the notch-free samples obtained fine cracks that reached 0.5 $\mu \mathrm{m}$ width, Figure 14(b). 

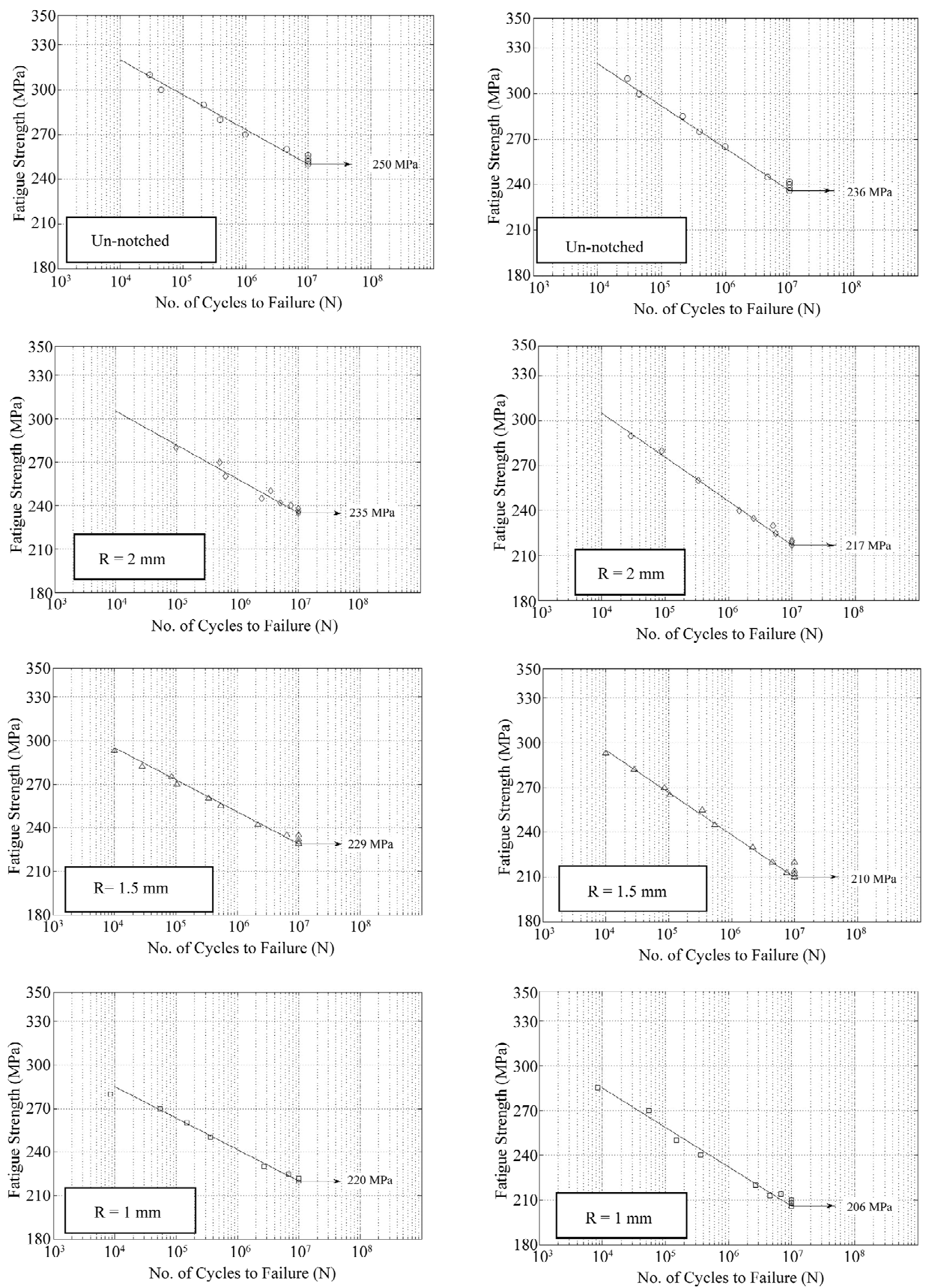

Austempering temperature of $350^{\circ} \mathrm{C}$

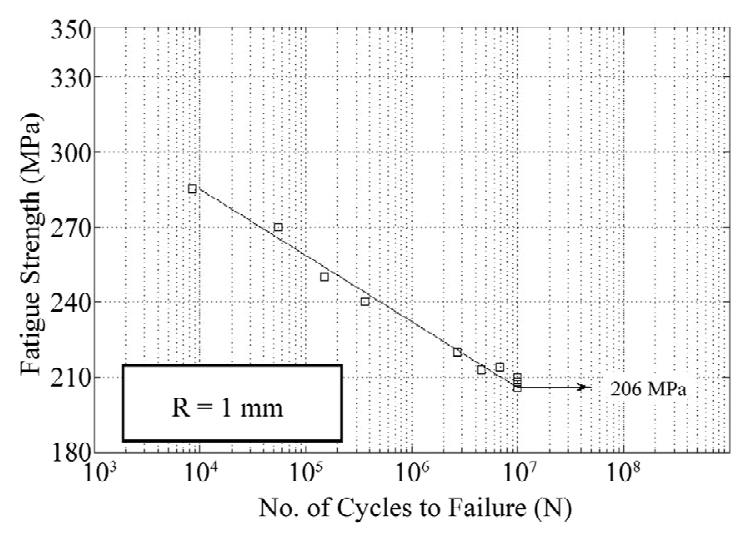

Austempering temperature of $400^{\circ} \mathrm{C}$

Figure 8. Experimental fatigue strength of the un-notched and notched ADI samples austempered at $350^{\circ} \mathrm{C}$ and $400^{\circ} \mathrm{C}$. 


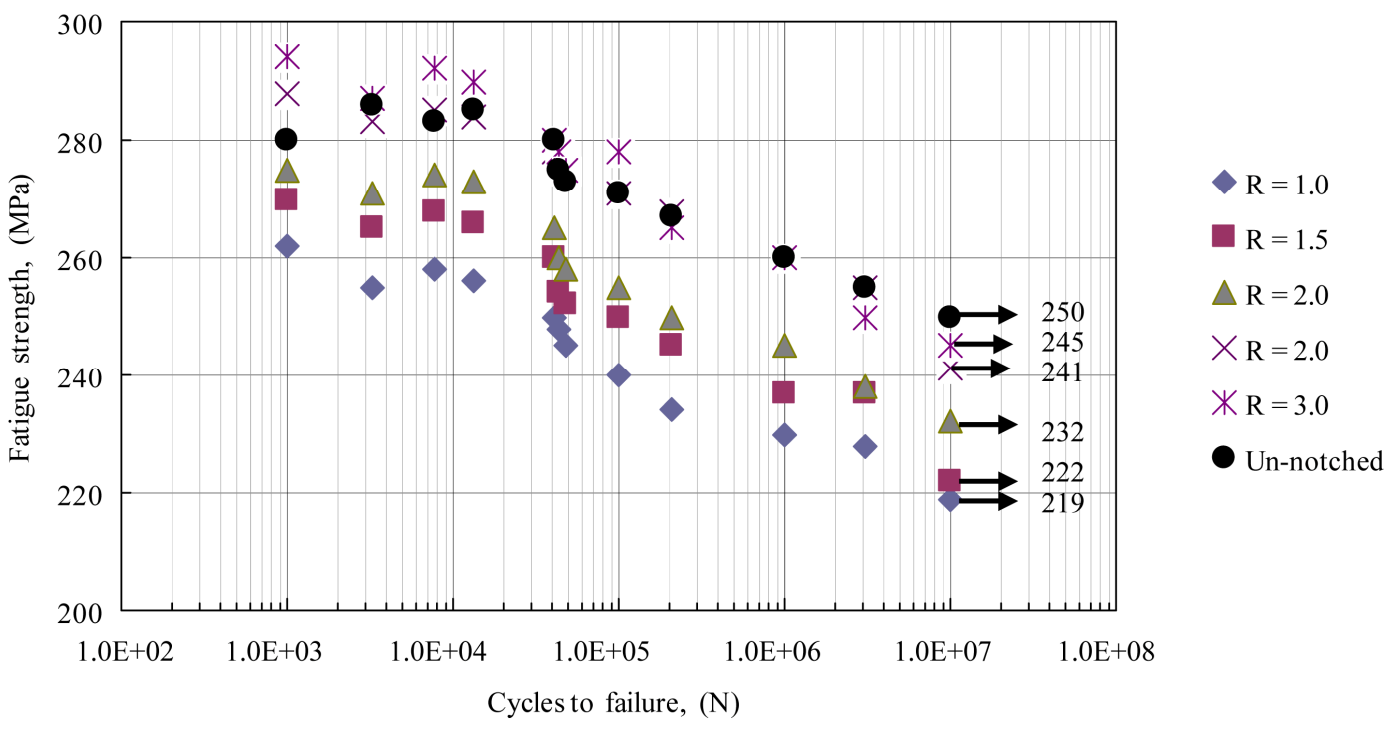

Figure 9. S-N curves for predicted samples austempered at $350^{\circ} \mathrm{C}$, un-notched and notched samples $(\mathrm{R}=1,1.5,2,2.5$ and 3 mm).

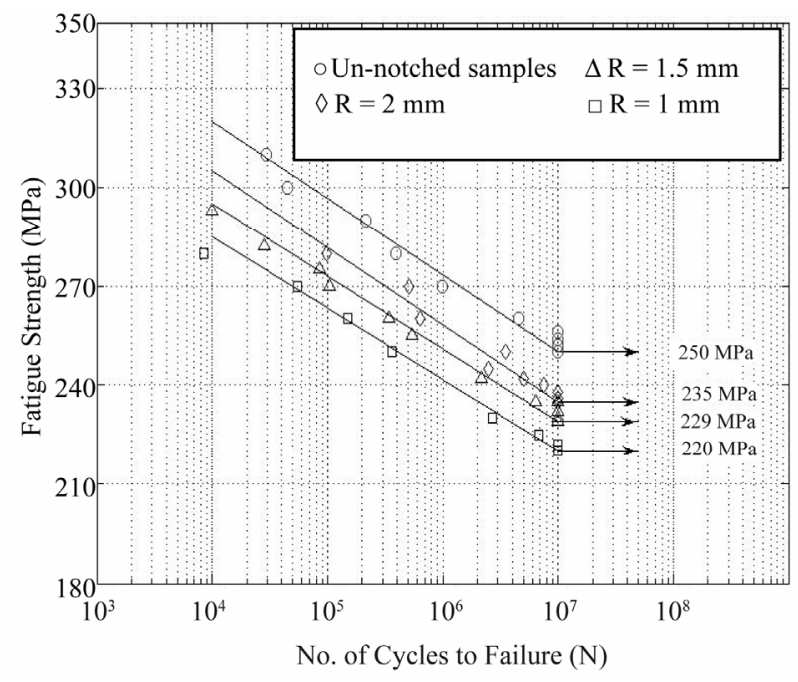

Figure 10. S-N curves for experimentally tested samples austempered at $350^{\circ} \mathrm{C}$, un-notched and notched samples $(\mathrm{R}=$ $1,1.5$, and $2 \mathrm{~mm}$ ).

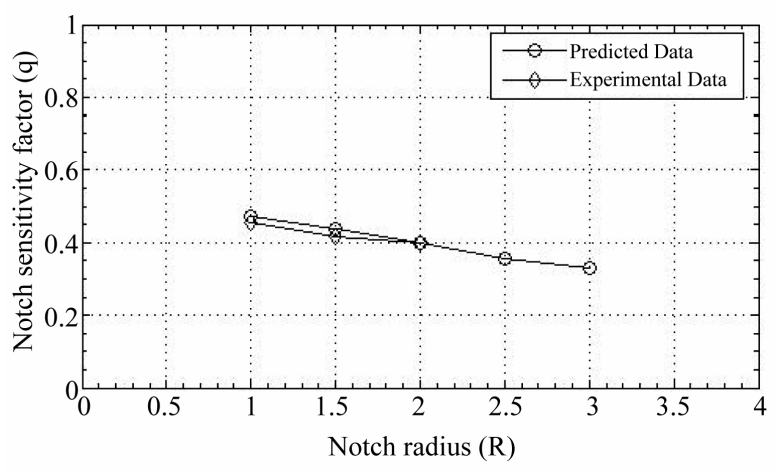

Figure 11. Comparison between experimental and predicted data for ADI austempered at $350^{\circ} \mathrm{C}$.

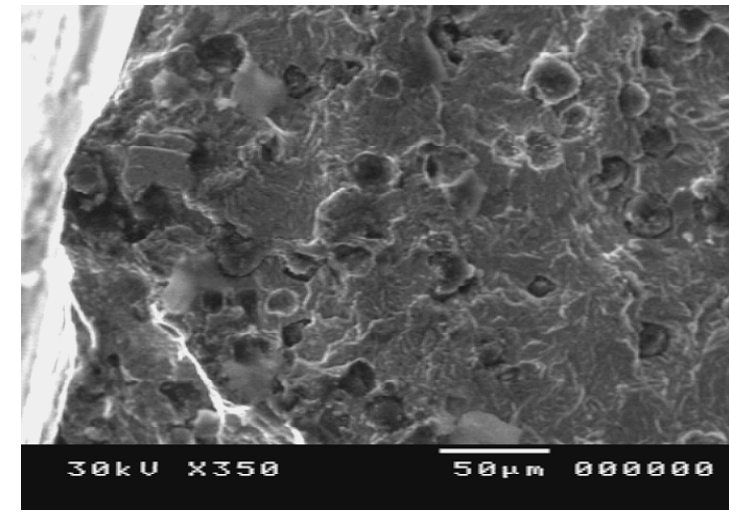

(a)

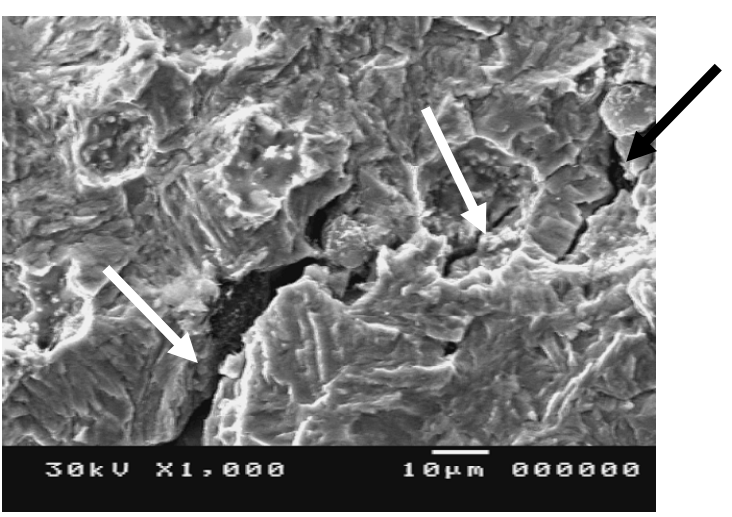

(b)

Figure 12. Fractography of the fatigue notched samples austempered at $350^{\circ} \mathrm{C}$.

\section{Conclusions}

1) Austempering temperature of $350^{\circ} \mathrm{C}$ obtained higher mechanical properties compared to $400^{\circ} \mathrm{C}$ due to the re- 
Table 3. Notch sensitivity factor (q) for $\mathrm{ADI} 900^{\circ} \mathrm{C} / 350^{\circ} \mathrm{C}$ and predicted data by ANSYS-12 calculations.

\begin{tabular}{|c|c|c|c|c|c|c|c|}
\hline \multirow{2}{*}{ R (mm) } & \multirow{2}{*}{$\mathbf{K}_{\mathbf{t}}$} & \multicolumn{2}{|c|}{ ADI $900^{\circ} \mathrm{C} / 350^{\circ} \mathrm{C}$} & \multicolumn{2}{|c|}{ ADI $900^{\circ} \mathrm{C} / 400^{\circ} \mathrm{C}$} & \multicolumn{2}{|c|}{ Predicted by ANSYS } \\
\hline & & $\mathbf{K}_{\mathbf{f}}$ & $\mathbf{q}$ & $\mathbf{K}_{\mathrm{f}}$ & $\mathbf{q}$ & $\mathbf{K}_{\mathbf{f}}$ & $\mathbf{q}$ \\
\hline 1.0 & 1.3 & 1.136364 & 0.4545 & 1.145631 & 0.4854 & 1.141553 & 0.471842 \\
\hline 1.5 & 1.21 & 1.086986 & 0.4141 & 1.113208 & 0.5390 & 1.091703 & 0.436681 \\
\hline 2.0 & 1.16 & 1.063830 & 0.3989 & 1.087558 & 0.5472 & 1.063830 & 0.398936 \\
\hline 2.5 & 1.13 & N/A & N/A & N/A & N/A & 1.046025 & 0.354039 \\
\hline 3.0 & 1.10 & N/A & N/A & N/A & N/A & 1.033058 & 0.330579 \\
\hline
\end{tabular}

$\mathrm{K}_{\mathrm{t}}$ : Stress concentration factor; $\mathrm{K}_{\mathrm{f}}$ : Fatigue notch sensitivity; q: Notch sensitivity factor.
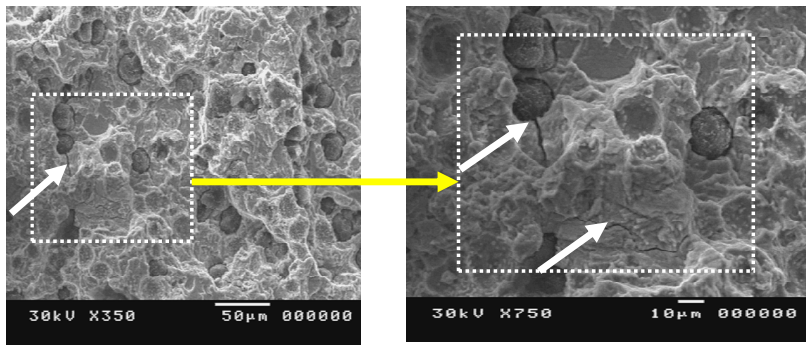

Figure 13. Fractography of the fatigue notch-free samples austempered at $350^{\circ} \mathrm{C}$.

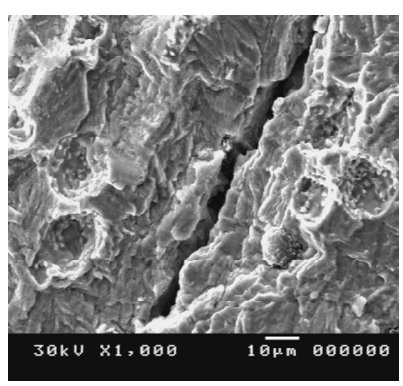

(a)

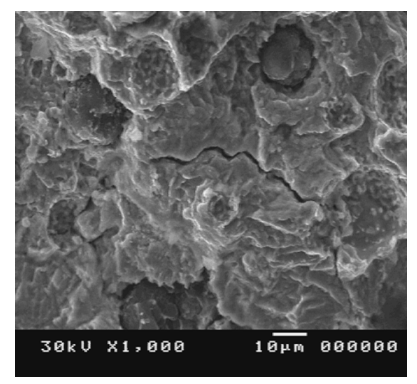

(b)
Figure 14. Fatigue crack width in both notched and notchfree samples austempered at $350^{\circ} \mathrm{C}$. (a) Notched samples; (b) Notch-free samples.

finement effect of the ausferritic structure and existing of less amount of retained austenite in matrix;

2) Fatigue strength vs. life time of ADI can be predicted using mechanical stress analysis ANSYS 12.0 which gave results that were very close to the experimental ones;

3) Fatigue performance of ADI of rotating parts made of ADI can be enhanced by increasing the fillet radius due to decreasing the notch sensitivity factor;

4) The decrease in fatigue strength with decreasing the notch radius was approximately the same for the studied samples austempered at $350^{\circ} \mathrm{C} \& 400^{\circ} \mathrm{C}$;

5) In machining spare parts made of ADI, it is recommended to use a notch radius more than 2-mm to keep the fatigue strength as high as possible to avoid failure in service.

\section{REFERENCES}

[1] B. Atzori, M. Zappalorto and F. Berto, "A Theoretical Treatise for Notch and Defect Sensitivity under Torsion," Mechanism Research Communications, Vol. 37, No. 2, 2010, pp. 173-176.

[2] C. Brunetti, M. V. Leite and G. Pintaude, "Effect of Specimen Preparation on Contact Fatigue Wear Resistance of Austempered Ductile Cast Iron," Wear, Vol. 263, No. 1-6, 2007, pp. 663-668.

[3] A. N. Damir, A. Elkhatib and G. Nassef, "Prediction of Fatigue Life Using Modal Analysis for Grey and Ductile Cast Iron," International Journal of Fatigue, Vol. 29, No. 3, 2007, pp. 499-507. doi:10.1016/i.ijfatigue.2006.05.004

[4] R. C. Dommarco and J. D. Salvanda, "Contact Fatigue Resistance of Austempered and Partially Chilled Irons," Wear, Vol. 254, No. 3-4, 2003, pp. 230-236.

[5] O. Eric, D. Rajnovic, S. Zec, L. Sidjanin and M. T. Jovanovic, "Microstructure and Fracture of Alloyed Austempered Ductile Iron," Materials Characterization, Vol. 57, No. 4-5, 2006, pp. 211-217.

[6] Y.-J. Kim, H. Shin, H. Park and J. D. Lim, "Investigation into Mechanical Properties of Austempered Ductile Iron (ADI) in Accordance with Austempering Temperature," Materials Letters, Vol. 62, No. 3, 2008, pp. 357-360.

[7] C. K. Lin, P. K. Lai and T. S. Shih, "Influence of Microstructure on the Fatigue Properties of Austempered Ductile Iron-I. High Cycle Fatigue," International Fatigue Journal, Vol. 18, No. 5, 1996, pp. 297-307. doi:10.1016/0142-1123(96)82895-7

[8] S. K. Putatunda, S. Kesani, R. Tackett and G. Lawes, "Development of Austenite Free ADI-Austempered Ductile Cast Iron," Materials Science and Engineering A, Vol. 435-436, 2006, pp. 112-122.

[9] P. P. Rao and S. K. Putatunda, "Investigation on the Fracture Toughness of Austempered Ductile Iron Alloyed with Chromium," Materials Science and Engineering A, Vol. 346, No. 1-2, 2003, pp. 254-265.

[10] P. A. S. Reed, R. C. Thomsin, J. S. James, D. C. Putman, K. K. Lee and S. R. Gunn, "Modelling Microstructural Effects in the Fatigue of Austempered Ductile Iron," Materials Science and Engineering A, Vol. 346, No. 1-2, 2002, pp. 273-286. doi:10.1016/S0921-5093(02)00545-2

[11] J. Speer, D. K. Matlock, B. C. De Cooman and J. G. 
Schroth, "Carbon Partitioning into Austenite after martensite Transformation," Acta Materialia, Vol. 51, No. 9, 2003, pp. 2611-2622.

[12] B. Stokes, N. Gao and P. A. S. Reed, "Effect of Graphite Nodules on Crack Growth Behaviours of Austempered Ductile Iron," Materials Science and Engineering A, Vol. 445-446, 2007, pp. 374-385.

[13] A. H. Elsayed, M. M. Megahed, A. A. Sadek and K. M. Abouelela, "Fracture Toughness Characterization of Austempered Ductile Iron Produced Using Both Conventional and Two-Step Austempering Processes," Materials \& Design, Vol. 30, No. 6, 2009, pp. 1866-1877.

[14] N. Elmasry, A. kandil, K. Abouelela and A. Amer, "Wear Behaviour of Austempered Ductile Cast Iron," Met-
all-Fourschung, Vol. 64, No. 1-2, 2010, pp. 353-357.

[15] M. Tayanc, K. Aztekin and A. Bayram, "The Effect of Matrix Structure on the Fatigue Behaviour of Austempered Ductile Iron," Materials and Design, Vol. 28, No. 3, 2007, pp. 797-803.

[16] J. Yang and S. K. Putatunda, "Near Threshold Fatigue Crack Growth Behaviour of Austempered Ductile Cast Iron (ADI) Processed by a Novel Two-Step Austempering Process," Materials Science and Engineering A, Vol. 393, No. 1-2, 2005, pp. 254-268.

[17] J. Zimba, D. J. Simbi and E. Navara, “Austempered Ductile Iron: An Alternative Material for Earth Moving Components," Cement \& Concrete Composites, Vol. 25, No. 6, 2003, pp. 643-649. 